\title{
THE APPLICATION OF JIGSAW COOPERATIVE LEARNING MODEL ON THE REACTION RATE MATERIAL TO TRAIN STUDENTS METACOGNITIVE SKILLS
}

\author{
Dini Madiar and Utiya Azizah* \\ Chemistry Education Study Program, Faculty Mathematics and Natural Science, Universitas Negeri Surabaya, \\ Surabaya, Indonesia \\ *Email: utiyaazizah@unesa.ac.id
}

Accepted: January 29, 2022. Approved: January 29, 2022. Published: January 30, 2022

\begin{abstract}
This study aims to describe the implementation of the Jigsaw type cooperative learning model, student activities in the application of learning models, students' metacognitive skills, and student responses to the applied learning model. This research targets 34 students of class XI MIPA 5 SMAN 19 Surabaya with a One Group Pretest Posttest Design research design. The results obtained are 1) the learning model implementation obtained $96.42 \%$ and 99.52\% with very good criteria. 2) The percentage of relevant student activities is greater than that of irrelevant students, namely $98.98 \%$ and $96.59 \%$. 3) The students' metacognitive skills increased with the average gain score obtained belonging to the high criteria, including Planning Skills 0.90; Monitoring skills 0.82; and Evaluating skills 0.83. 4) Students' response to the applied learning model is good, where $93.3 \%$ of students respond positively.
\end{abstract}

Keywords: Cooperative Learning model, Jigsaw, Metacognitive

\section{INTRODUCTION}

Education is one of efforts or efforts that has been done to conduct a learning process that aims to develop skills and four "developing students behavior [1]. The signs of a country's success can be measured from the country's quality and level of education. With a good quality of education, Indonesian can be human beings who fear God Almighty, noble, creative, and responsible. The Indonesian must efforts to achieve that success aims to enhance Indonesia's education quality. In Indonesia, the 2013 curriculum, which was started in 2013 til 2014, is now being implemented at the senior high school level. 2013 curriculum was conceptualized to prepare the youth's future that needs observation, communication, and communicating what they had learned at school[2]. At the high school level, students must think reflectively, critically, and analytically, which significantly empowers metacognitive abilities[3]. The teacher asked students to memorize the material, and both graduated from the teacher without critically reflecting on their learning experience. Therefore, the teaching process in the classroom cannot work optimally. Of course, on the contrary, the 2013 curriculum requirements prioritized process skills and focused on two competencies: opinion competence and communicative competence[4]. Students at the high school level are required to have the ability to think reflectively, critically, and analytically, which significantly empowers metacognitive skills [5]

As an educator, the teacher needs to motivate, innovate, and be creative in delivering the materials to become way more motivated to study. However, preobservation conducted in SMA Negeri 19 Surabaya shows that teachers are still implementing the traditional learning delivery method. It made the students feel bored most of the time during the learning process. If the chemistry is a branch of sciences that studies facts, concepts, regulations, laws, principles, and theories, that means chemistry's scope is broad. Chemistry in high school is considered difficult by students. It has been proven by the preliminary study conducted on November $3^{\text {rd }}, 2021$, in SMA Negeri 19 Surabaya, in which $87,5 \%$ of the students considered chemistry as a complex subject. One of the chemistry materials at the Senior High School level is reaction rate. Reaction rate studies the factors impacting reaction rate; concentration, surface area, temperature, and catalyst. Based on the previous survey's data, $87,5 \%$ of students feel confused most of the time while studying reaction rate. It is because the material has an abstract concept, and to understand fully about reaction rate needs to exercise.

Metacognition is thinking about thinking or cognition about one's awareness which aims to improve learning and solve a problem[6]. Flavell (1979) suggests that metacognition includes two components, namely metacognitive knowledge and metacognitive experience[7]. Ability in metacognitive consists of two parts: metacognitive knowledge and metacognitive skills[8]. Skills metacognition is a skill that processes one's mind well to use the knowledge he already has, reflecting and controlling the processes and outcomes of the thought itself[9]. Metacognitive strategies can be described as procedures, which are specific thought processing activities that are part of a complex process and are carried out to achieve goals such as reading comprehension[10]. Metacognitive refers to knowledge and students' cognitive activities skills that probably allow them to understand their knowledge [11]. In this case, metacognitive skills are essential in preparing to learn from something, monitoring improvement in learning outcomes, and correcting what has been known in solving a problem[12]. The courses they can achieve are by studying these students. Some elements of metacognitive skills need to be understood to achieve 
that goal; planning, monitoring, and evaluation[13]. However, the previous survey's data on November $3^{\text {rd }}$, 2021 , shows that only $31.3 \%$ of students implemented planning before starting their chemistry class, $18.8 \%$ of students monitored the chemistry learning process, and $40.6 \%$ of students evaluated the learning process that I conducted. It is necessary to have an innovative learning model as educators that train the students' metacognitive skills.

Applying the cooperative learning model Jigsaw could enhance the students to achieve a learning milestone of achievements. The Jigsaw cooperative learning model is by the wishes or convenience of students in the learning process, namely through grouping and sharing. The application of the Jigsaw Model requires all students to be responsible to all members of their respective groups to understand the material or problems discussed in their groups[14]. Students generally best understand what is learned according to the characteristics of the cooperative learning model by grouping or sharing it with colleagues or learning partners[15]. This learning model allows students to work together in a team[16]. It is to ease the students in understanding the materials that they studied. This application of the cooperative learning model Jigsaw demands all the students to be responsible for the materials they looked [17].

\section{RESEARCH METHODS}

Types of research used were quasiexperimental research with research objectives of students in a class of XI MIPA 5 SMA Negeri 19 Surabaya with 34 students as the participants. They were done during the odd semester 2021-2022 up to 2 meetings. The design of this research was Group PreTest Post-test Design. A preset data collection was conducted before applying the learning model, and a posttest was also completed after the learning process. The learning media used in this research was syllabus, Lesson plan with Jigsaw cooperative learning model, and Worksheet adapted from Malinda and Azizah[18]. Some research instruments are used Jigsaw cooperative learning model implementation. Students' activities were observed by pretest-posttest questions integrating metacognitive skills, and students' response questionnaires support this research. Sheets of learning model implementation consist of the syntax of the Jigsaw cooperative learning model held during the investigation. The syntax of the cooperative model includes conveying goals and motivating students, presenting information, dividing students into study groups, guiding groups to work and study, evaluating, and providing rewards related to students' thinking processes[19]. To analyze this application of learning model data is necessary to use the scoring analysis. The scoring criteria for applying the syntax of the Jigsaw cooperative learning model can be seen in Table 1.
Table 1. Scoring Criteria for Learning Model Implementation Sheet

\begin{tabular}{cl}
\hline Score & \multicolumn{1}{c}{ Criteria } \\
\hline 0 & $\begin{array}{l}\text { Didn't implement the learning step. } \\
\text { Did the learning step incomplete but } \\
\text { coherent. }\end{array}$ \\
2 & $\begin{array}{l}\text { Did the learning step complete but not } \\
\text { coherent. } \\
\text { Did the learning step complete and } \\
\text { coherent. }\end{array}$ \\
\hline
\end{tabular}

Data gathered later converted into a new form of scores, as attached below.

$$
\text { Score }=\frac{\text { total score gained }}{\text { Maximum score }} \times 4
$$

Then we can find the average scores from the data obtained with the following formula.

Average Score $=\frac{\text { total score gained by the observe }}{d \text { total number of observes }}$

The following formula converts the value of the implementation of the learning model.

$$
\text { Presentation value }=\frac{\text { total value gained }}{\text { maximum total value }} \times 100
$$

There are also criteria for the limiting scores for implementing the learning model, as shown in the following table.

Table 2. Criteria for limiting scores for the Implementation of the Learning Model

\begin{tabular}{cll}
\hline No. & \multicolumn{1}{c}{ Range } & \multicolumn{1}{c}{ Criteria } \\
\hline 1. & $1 \%-20 \%$ & Very Bad \\
2. & $21 \%-40 \%$ & Bad \\
3. & $41 \%-60 \%$ & Neutral \\
4. & $61 \%-80 \%$ & Good \\
5. & $81 \% 100 \%$ & Very Good \\
\hline
\end{tabular}

Jigsaw cooperative learning model generally in every meeting can be concluded as a success it is in the good and very good category with a percentage of $\geq 61 \%$.

The sheets of students' activities can be analyzed through the percentages of each activity that appear dominantly, where that percentage can be counted through the following formula.

$$
\% \text { students activities }=\frac{\text { frequency of activities }}{\text { total activity frequency }} \times 100
$$

Students activities in a group can be concluded as a success if the percentage is $\geq 75 \%$ and bigger than the irrelevant activities percentage.

On the pretest and posttest, which were used to integrate the metacognitive skills in which on the test sheets, 20 essay questions consisted of Planning, Monitoring, and Evaluating. Data will be analyzed through the pretest and posttest sheets on each component of metacognitive skills in the following ways. 


$$
\text { score }=\frac{\text { Total gained score }}{\text { maximum score }} \times 100
$$

Scores obtained will be tested with a normality test that the Paired Sample T-Test will follow on SPSS. If the value sig. (2-Tailed) gained is smaller than 0,05 , there are differences in results between the pretest and posttest on components of students' metacognitive skills.

Data of value obtained from the pretest and posttest can be analyzed with the gain score equation that can be calculated with the following formula

$$
\text { gain score }=\frac{\text { score post test }- \text { score pretest }}{\text { score maximum }- \text { score pretest }} \times 100
$$

Based on the gain score to discover the students' metacognitive skills between the pretest and posttest obtained, it can be converted with the criteria of gain score level as shown in the table below.

Table 3. Criteria of Gain Score

\begin{tabular}{ll}
\hline \multicolumn{1}{c}{ Score } & \multicolumn{1}{c}{ Criteria } \\
\hline $\mathrm{g} \geq 0,7$ & High \\
$0,3 \leq \mathrm{g}<0,7$ & Medium \\
$\mathrm{g}<0,3$ & Low \\
\hline
\end{tabular}

The students' metacognitive skills can be exercised through the Jigsaw cooperative learning model if the gain score is placed between $0,3 \leq \mathrm{g}<0,7$ with the Medium criteria.

On the sheets of metacognitive inventory and the students' response questionnaires, the support is used after the students get the Jigsaw cooperative learning model treatment on the reaction rate material. Metacognitive inventory and student response questionnaires are given to students through Google Form, which consists of multiple questions responding to the learning model applied.

\section{RESULT AND DISCUSSION The Application of Jigsaw Cooperative Learning Model}

The application sheets of the Jigsaw cooperative learning model obtain data through 3 observers, which are the Chemical students of Surabaya State University and chemistry teachers of XI MIPA 5 in SMA Negeri 19 Surabaya. This observation was conducted twice in which this analysis aimed to describe the implementation of the learning model, whether it is already in accordance with the previously validated lesson plan. The application sheets of the Jigsaw cooperative learning model consists of 6 phases[20]

Phase 1 is clarifying the goals and operating the establishing set. In this phase, the teachers are to deliver the purposes of the learning process that will be conducted and give the students motivations such as daily life phenomena relating to the factors impacting to reaction rate. Phase 2 provides information where teachers deliver information regarding the factors affecting reaction rate in general. Phase 3 is organizing students into a group of learners. In this phase, the teacher divided students into six groups of 5-6 students in each group as the home groups. Fitting in with the Jigsaw learning model, the teacher divided those home groups into two groups consisting of 3 students as the expert groups. In an expert group, each student will have responsibilities regarding the sub-materials that will be gotten from the expert group, which later on would be demonstrated to the home groups. Phase 4 is guiding groups to work and learn where. In this phase, the teacher helped the students to witness practicum virtually, determining goals (planning), identifying problems, conceptualizing formulation of problems, framework hypothesis (monitoring), until concluding the learning evaluation (evaluating). Phase 5 is considering that the teacher demanded the students go back to their home groups to demonstrate the information obtained from the expert group and present it. Phase 6 is rewarding in which the teacher would give a reward in the form of stationary for the student with the best posttest score.

The results of the data analysis of the application of the Jigsaw cooperative learning model as a whole at the first meeting obtained a percentage result up to $96.42 \%$, meaning that the application of the learning model was conducted very well. The results of data analysis of the application of the Jigsaw cooperative learning model as a whole at the second meeting obtained a percentage result up to $99.52 \%$, proving that the application of the learning model was conducted very well.

\section{Students Activities}

Three observers observed students' activities: Chemistry college students at Surabaya State University and chemistry teachers of XI MIPA 5 in SMA Negeri 19 Surabaya. The observation sheets were observed for about 60 minutes or 2 hours of learning every 3 minutes, where every observer watched two groups each meeting. Here is the table of results of average percentages of students' activities.

Table 4. Percentage data of Students Activities

\begin{tabular}{ccc}
\hline & Average of & Average of \\
Meetings & Relevant & Irrelevant \\
& Activities & Activities
\end{tabular}

$\begin{array}{lll}\text { Meeting } 1 & 98,98 \% & 1,02 \% \\ \text { Meeting 2 } & 96,59 \% & 3,41 \%\end{array}$

Students' metacognitive skills could be trained by applying the Jigsaw cooperative learning model in the lesson plan and Worksheet. The percentage results of students' activities at each meeting are different. At the first meeting, the learning process discussed the effect of temperature and concentration factors on the reaction rate. The second meeting discussed the effecting aspects of surface area 
and catalyst to reaction rate. On Planning, Skills students could be trained by conducting activities such as communicating the purpose of the experiment based on the phenomenon that has been given previously during the learning process. Besides that, activities such as discussing identifications on Worksheet regarding the factors affecting reaction rate, formulating problems, framework hypotheses can also practice the Students' Planning skills. Every group did activities such as witnessing practicum video through Zoom. This thing could make every student able to cooperate reasonably with their partners. The first meeting was seeing a practicum video about temperature and concentration on reaction rate. The second meeting witnessed a practice video about surface area and catalyst's effect on reaction rate. The video was accessed through the link attached on Worksheet 1 (temperature), Worksheet 2 (concentration), Worksheet 3 (surface area), Worksheet 4 (catalyst). Activities such as Monitoring Skills can be conducted by handling a group discussion and creating important notes regarding information such as experimental data obtained after watching the practicum. Conclusion making essential points regarding the materials of factors affecting the reaction rate with the teachers can train students' metacognitive skills, which is Evaluating Skills.

The closing activity rewarded the most active group and students with the highest and the best posttest score. Relevant students activities percentage is more significant than irrelevant students activities percentage. It results in the student's actions during the two meetings with the well-implemented learning model, proven by the percentage data on the table shown above.

\section{Metacognitive Skill}

Metacognitive skill is a skill that a person has to manage their way of thinking by using information or knowledge obtained, controlling or monitoring their thought process, and reflecting[15].

On metacognitive skills, there are three essential skill components which are planning (Planning Skills), monitoring (Monitoring Skills), and evaluating (Evaluating Skills). In this research, two types of tests that needed to be implemented by the students were the pretest questions conducted before the learning process and posttest questions completed after the learning process. The questions on these tests had gone through a validation process carried out by chemistry lecturers with feasibility criteria to use. On each trial, there were 20 essay questions, in which every factor affecting the reaction rate consisted of 5 questions that have been integrated metacognitively.

The students' metacognitive skills can be valued through several activities, including determining their learning purposes at first before starting the learning process, identifying problems based on the phenomenon, until concluding. Before starting learning, identify a problem based on the phenomenon to complete. The students' data of metacognitive skills were analyzed on each component. The Criteria for metacognitive skills in students can be determined through the gein score criteria as the table 5 .

Table 5. Criteria of Gain Score

\begin{tabular}{ll}
\hline \multicolumn{1}{c}{ Score } & \multicolumn{1}{c}{ Criteria } \\
\hline $\mathrm{g} \geq 0,7$ & High \\
$0,3 \leq \mathrm{g}<0,7$ & Medium \\
$\mathrm{g}<0,3$ & Low \\
\hline
\end{tabular}

Here are the results of the data analysis of the students' metacognitive skills.

Table 6. Data of score of the students' average cognitive skill

\begin{tabular}{lccc}
\hline $\begin{array}{c}\text { Metacognitive } \\
\begin{array}{c}\text { Skill } \\
\text { Components }\end{array}\end{array}$ & Pretest & Posttest & $\begin{array}{c}\text { Gain } \\
\text { Score }\end{array}$ \\
\hline Planning Skills & 47,93 & 91,45 & 0,90 \\
$\begin{array}{l}\text { Monitoring } \\
\text { Skills }\end{array}$ & 40,90 & 89,90 & 0,82 \\
Evaluating Skills & 42,40 & 90,40 & 0,83 \\
\hline
\end{tabular}

Based on the data managed in the table above, it is known that applying the Jigsaw cooperative learning model on each metacognitive skill component is placed in high criteria. It proves that the Jigsaw cooperative learning model can train the students' metacognitive skills.

On the component of Planning Skills, the students conducted a learning planning activity first, just like how they determined their learning purposes. After the students understood their learning purposes, such as understanding the effect of temperature factor, concentration, surface area, and catalyst towards the reaction rate. The students would be so much easier to finish a specific problem about reaction rate.

On the component of Monitoring Skills, students researched the factors affecting reaction rate, such as determining formulation of problems, identifying specific issues, and creating important notes in the form of a table based on the experimental data obtained. With this, the students could easily conclude the ongoing problems.

On the component of Evaluating, students' skills were trained to make a conclusion based on the analysis of experimental data conducted. Based on the answers given by the students, it shows that students were able to do the posttest very well and correctly. It shows that the students' metacognitive skill is successfully trained with the help of the Jigsaw cooperative learning model. The gain score criteria obtained met the highest criteria.

\section{Students' response questionnaire}

The sheet of student questionnaire consists of supporting questions about the students' response 
towards the learning model implemented. This response questionnaire sheet was shared through Google Form with 34 respondents. On the analysis conducted with the Jigsaw cooperative learning model, $93.3 \%$ of students felt their understanding of the materials of factors affecting the reaction rate enhanced. Besides that, with the application of the Jigsaw cooperative learning model, $86.7 \%$ of students were able to finish on-going problems about factors affecting reaction rate. Based on that data, it can be concluded that the Jigsaw cooperative learning model received a good response from the students and completed to have successfully enhanced the students' understandings regarding the materials of factors affecting reaction rate.

\section{CONCLUSION}

Based on the result and discussion, several conclusions were obtained. The results of applying the Jigsaw cooperative learning model on the first and second meetings were received with very good criteria. Students' activities during the learning process are classified as good. It is proven by acquiring the percentage of relevant student activities that is bigger than the percentage of irrelevant student activities during two meetings. The students' metacognitive skill was enhanced. The average gain score obtained proves this is classified as high criteria. The students' response towards applying the Jigsaw cooperative learning model was to train the metacognitive skill on the reaction rate material to get a good response.

\section{DAFTAR PUSTAKA}

[1] Flavell, J. H. (1979). Metacognition and cognitive monitoring: A new area of cognitivedevelopmental inquiry. American psychologist, 34(10), 906.

[2] Azwar, S.(2011) Sikap Manusia: Teori dan Pengukurannya (Edisi 2). Yogyakarta: Pustaka Pelajar.

[3] Wahdah, N. F., Jufri, A. W., \& Zulkifli, L. (2016). Jurnal Belajar Sebagai Sarana Pengembangan Kemampuan Metakognisi Siswa. Jurnal Pijar Mipa, 11(1)..

[4] Apriadi, R., Andayani, Y., \& Muntari, M. (2018). Pengembangan Modul Pembelajaran Kimia Berbasis Pendekatan Saintifik Untuk Siswa Sma. Jurnal Pijar Mipa, 13(2), 171-176.

[5] Wilson, D. \& Conyers M. (2016). Teaching Student to Drive Their Brains: Metacognitive Strategies, Activities, and Lesson Ideas. New York: Eastern Suffolk BOCES.

[6] Anita, W. (2008). Educational Psychology, Active Learning Edition.

[7] Hacker, D. J., Dunlosky, J., \& Graesser, A. C. (Eds.). (2009). Handbook of metacognition in education. Routledge..

[8] Schraw, G., \& Dennison, R. S. (1994). Assessing metacognitive awareness. Contemporary educational psychology, 19(4), 460-475.
[9] Pulmones, R. (2007). Learning chemistry in a metacognitive environment. The Asia-Pacific Education Researcher, 16(2), 165-183.

[10] Haris, M., Muntari, M., \& Loka, I. N. (2019). Penerapan Pembelajaran Kooperatif Terpadu NHT dan TSTS Dalam Mengatasi Kesulitan Belajar Struktur Atom dan Sistem Periodik Unsur. Jurnal Pijar Mipa, 14(3), 123-127.

[11] Sudjana, N., \& Rivai, A. (1990). Media Pengajaran: penggunaan dan pembuatannya. $\mathrm{CV}$ Sinar Baru, Bandung.

[12] Depdiknas. (2003). Undang-undang RI No.20 tahun 2003, tentang sistem pendidikan nasional. Jakarta: Depdiknas.

[13] Okumus, S., Koc, Y., \& Doymus, K. (2019). Determining the Effect of Cooperative Learning and Models on the Conceptual Understanding of the Chemical Reactions. Educational Policy Analysis and Strategic Research, 14(3), 154-177.

[14] Sukarini, A., Susilowati, E., \& Martini, K. S. (2013). Studi Komparasi Pembelajaran Kimia Menggunakan Metode Jigsaw dan Cooperative Integrated Reading and Composition (CIRC) Terhadap Prestasi Belajar Siswa pada Materi Koloid Kelas XI Semester 2 SMA Negeri 1 Wonogiri Tahun Ajaran 2011/2012. Jurnal Pendidikan Kimia, 2(3), 77-84.

[15] Ismail, I. (2020). The Application of Jigsaw Cooperative Learning Model towards the Improvement of Students' Critical Thinking Ability in Public Senior High School 15 Banda Aceh, Indonesia. Budapest International Research and Critics in Linguistics and Education (BirLE) Journal, 3(2), 1113-1122.

[16] Mahmuda, S., \& Azizah, U. (2020). Penerapan Model Pembelajaran Kooperatif Tipe NHT untuk Melatihkan Keterampilan Metakognitif pada Materi Asam Basa Kelas XI SMAN 1 Waru. UNESA Journal of Chemical Education, 9(3), 417-426.

[17] Hasanah, I. (2016). Penerapan Model Pembelajaran Kooperatif Tipe Jigsaw Dengan Strategi Metakognitif Maateri Koloid Kelas Xi Semester Genap Di Sman 2 Bangkalan (Implementation Of Jigsaw Cooperative Learning Model By Metacognitive Strategi On Subject Matter Of Koloid In Sman 2 Bangkalan). Unesa Journal Of Chemical Education, 5(3).

[18] Malinda, W. F., \& Azizah, U. (2019). Penerapan Model Pembelajaran Kooperatif NHT Untuk Melatihkan Keterampilan Metakognitif Pada Materi Laju Reaksi Kelas Xi Sma Negeri 4 Sidoarjo. UNESA Journal of Chemical Education, 8(2).

[19] Azizah, U., \& Nasrudin, H. (2018). Empowerment of metacognitive skills through development of instructional materials on the topic of hydrolysis and buffer solutions. In Journal of Physics: Conference Series (Vol. 953, No. 1, p. 012199). IOP Publishing. 
[20] Arends, RI (2008). Learning to Teach. Buku I. Edisi Ketujuh. Cetakan Pertama. Yogyakarta: Pustaka Pelajar

[21] Irawan, J., Hadi, S., Zulandri, Z., Jamaluddin, J., Syukur, A., \& Hadisaputra, S. (2021). Validating metacognitive awareness inventory (MAI) in chemistry learning for senior high school: A rasch model analysis. Jurnal Pijar Mipa, 16(4), 442448. 